\title{
Electronic Customer Relationship Management Information Systems of Sharia Life Insurance at AJB Bumiputera 1912
}

\author{
Bayu Waspodo ${ }^{a^{*}}, Z_{\text {Zulfiandri }}$, Afifah Fajric \\ a,b,c Department of Information Systems \\ Syarif Hidayatullah State Islamic University Jakarta \\ Tangerang Selatan, Indonesia \\ *Email: bayu.waspodo@uinjkt.ac.id
}

\begin{abstract}
Sharia individual life insurance products depends on Bumiputera agents to provide services related to the product and its policies. Related to get new customers and to maintain good relations with its customers. Problems occurs where such services cannot accommodate the needs of the public and participants for fast and clear information. It causes unknowingly sharia life insurance Bumiputera by people, the slow production growth of Bumiputera sharia life insurance and threatening to Bumiputera in maintaining its presence and its loyal customer. Bumiputera need to improve their services by designing and developing an Electronic Customer Relationship Management (e-CRM) information systems for sharia life insurance based on the net technology CRM Operations. Methods used is waterfall models with UML notations. Research output is to facilitate the public and customers in getting AJB Bumiputera 1912 product or policy life insurance sharia services using net technology.
\end{abstract}

Keywords: Bumiputera, CRM, Operational CRM, E-CRM, sharia life insurance

\section{Introduction}

Business growth, especially in the life insurance industry today is growing rapidly and competition among competitors even more stringent to make the company must continue to improve its business, whether it's the quality of the products or the services.

This is also supported by the growth of net technology which is now a media of information is growing very fast. Internet (net) can be accessed from anywhere and provide a lot of convenience, especially the ease to communicate quickly with a broad range and gain and provides the opportunity to bring information, knowledge, and support automation for daily business activities.

AJB Bumiputera 1912 is one of the leading life insurance companies in Indonesia. Although a conventional company, AJB Bumiputera 1912 in his growth has opened a sharia business unit in 2002 and began operating in 2003 and offering sharia life insurance products, including 'Mitra Mabrur Plus', 'Mitra Iqra Plus', and 'Mitra Amanah' as individual sharia life insurance products, 'Mitra Ekawarsa', 'Mitra Perlindungan Kecelakaan Diri', and 'Mitra Ta'awun.

Table 1. Portfolio Policy of Sharia Business Unit AJB Bumiputera 1912

\begin{tabular}{|l|l|l|}
\hline \multirow{2}{*}{$\begin{array}{l}\text { Sharia Business } \\
\text { Unit }\end{array}$} & \multicolumn{1}{|l|}{ Policy } & \multicolumn{1}{c|}{ Customer } \\
\cline { 2 - 3 } & \multicolumn{2}{|l|}{ (until December 2015) } \\
\hline Individual & 134.871 & 134.871 \\
\hline Group & 2.670 & 66.094 \\
\hline Total & 137.541 & 204.469 \\
\hline
\end{tabular}

Source: AJB Bumiputera 1912 (2016)

It suggests that the public interest in the sharia life insurance products were offered AJB Bumiputera 1912. However, this has not been followed by an increase in service to the sharia life insurance Bumiputera customers to get more new customers, enhance good relations with the customers, as well as to maintain loyalty customers by utilizing the technology's growing, while the level of aggressiveness of competitors in dominating market share is very high because it has been supported using the latest technology in service to its customers.

The current problem is Bumiputera still rely heavily in agency system to marketing and provide information services to the public, as well as maintaining relationships with its customers. It is quite good, as the business growth of the life insurance industry in Indonesia now, Bumiputera has lagged in terms of service to its customers. Although the company already has a website, but the website has not been able to provide information and other services clearly, particularly in sharia life insurance. This could be a threat for Bumiputera because more people are better utilized net technology to find the information they need. As stated by Mr. Faizal Fahd as one of the agency staff Syariah Division AJB Bumiputera 1912 that so far, the company website provided information were deemed to be inadequate for sharia business lines. Here is marketing performance of Sharia Business Unit AJB Bumiputera 1912 achievement data in period of January 1 to December 31, 2015. 
Table 2. Operational Performance of AJB Bumiputera 1912

Sharia Business Unit (AJB Bumiputera 1912, 2016)

\begin{tabular}{|c|c|c|c|c|}
\hline \multirow{2}{*}{ 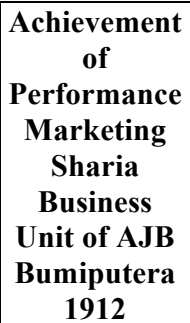 } & \multicolumn{2}{|c|}{ TARGET } & \multicolumn{2}{|c|}{ REALIZATION } \\
\hline & 2014 & 2015 & 2014 & 2015 \\
\hline SPAJ & 44.100 & $\begin{array}{l}38.76 \\
2\end{array}$ & $\begin{array}{l}18.515 \\
(41,98 \\
\%)\end{array}$ & $\begin{array}{l}13.611 \\
(35,12 \%)\end{array}$ \\
\hline
\end{tabular}

The service system that still very reliable by AJB Bumiputera 1912 is a service agent in prospecting and after sales services activities. In the prospecting activity of potential customers, the agent must search for and prepare a list of prospects that will be visited before. Agents usually ask for references from customers in the insurance market segment or region of production and from the policy portfolio. However, if the customer wants to provide a reference to agents, customer should contact his agent first. This of course causes few problems when prospects referenced by the customer are not in this market segment and region of production, so it will take some time for these prospects to be served by the agency in accordance with the referenced area prospects.

Similarly, in after sales services, to request information about the policy (policy status, due date for payment of contributions, confirmation of payment of contributions, filing a claim), customers usually must go through an agent or customer service/sharia branches office of AJB Bumiputera 1912. Agent/customer service will provide the requested information and often then print and send them by fax. Although considered effective, information services certainly require more time, effort, and cost so it becomes less efficient for the company as well as for customers because it is not flexible in terms of time.

Problems identifications of this study are:

1. Limitations of media marketing and information services for public causes public difficulty in accessing information on the AJB Bumiputera 1912 and sharia life insurance products are offered because have to through the agent or branch offices as well as causing the least sharia life insurance production growth.

2. The customer service is still not optimum because sharia life insurance customers of AJB Bumiputera have not been able to get information and policy services they need as quick and independent as possible, so customers should look for the information they need by itself to sharia branch offices or through an agent.

Based on the identification of the above problems, it can be formulated and will be discuss in this research is how to design Electronic Customer Relationship Management (e-CRM) information systems on sharia life insurance at AJB Bumiputera 1912?. The problem limitations of this study are:
1. Design and development of sharia life insurance services information systems based Electronic Customer Relationship Management (E-CRM) is intended for Sharia Division of AJB Bumiputera 1912.

2. The system developed is destined to the Islamic business units AJB Bumiputera 1912, namely Sharia individual life insurance products especially Mitra Mabrur Plus as one of the products with the highest interest based on survey results.

3. The type of CRM used is Opera-tional CRM in the form of web-based applications. The system is limited to the activities of service to the public/prospects and sharia life insurance AJB Bumiputera 1912 customers, such as company and sharia life insurance product information services for the public/prospects, request a visit agents and policy online services specially for the customers such as information on the payment due date of contributions, policy consultation, confirmation of payment of contributions, claims and references new prospects.

4. The method used in the development of the system is the Waterfall model up to the stage of testing (testing system).

5. Tools used in the design of the system is Unified Modelling Language (UML) to describe the use case diagram, activity diagram, class diagram, sequence diagram, component diagram, and deployment diagram.

The general objective of this study is to produce an Electronic Customer Relationship Management (e-CRM) information system on sharia life insurance products AJB Bumiputera 1912 that can help attract new customers and maintain or even increase customer loyalty that can be benefit companies by providing clear information, fast, and up to date and improve web-based services related products and sharia life insurance policies where they can compete, thrive, and continue to exist from their competitors in the life insurance industry in Indonesia.

\section{Literature Review}

\subsection{Information Systems Definition}

The information system as defined by the Robert A. and $\mathrm{K}$. Roscoe Laitch Bavis as a system within an organization reconcile the needs of daily transaction processing, support the operation, managerial and strategic activities of an organization and provide certain out-side parties with the necessary reports (Kusrini and Koniyo, 2007) [1].

Similar but more comprehensive, information systems define as a system which consists of several main components that cooperate or associated or connected to each other, i.e. human, hardware, software, communication networks and data sources/databases in the process of the activities of collecting, processing, storing, analyzing and disseminating data to achieve a specific goal that has been sets (Waspodo, 2008) [2].

\subsection{Customer Relationship Management (CRM) \\ Definition}

CRM is the core business strategy that integrates internal processes and functions, and external networks, to create and deliver value to targeted customers at a profit. 
(Buttle, 2009) [3]. Buttle (2009) [4] stated four types of CRM, namely:

\section{Strategic CRM}

Strategic CRM is focused upon the development of a customer-centric business culture by creating and delivering value better than competitors.

\section{Operational CRM}

Operational CRM automates and improves customerfacing and customer-supporting business processes. CRM software applications enable the marketing, selling and service functions to be automated and integrated.

\section{Analytical CRM}

Analytical CRM is concerned with capturing, storing, extracting, integrating, processing, interpreting, distributing, using and reporting customer-related data to enhance both customer and company value. Analytical CRM builds on the foundation of customer-related information.

\section{Collaborative CRM}

Collaborative CRM applies techno-logy across organizational boundaries with a view to optimizing company, partner and customer value. [5]:

The three phases of CRM according to O'Brien (2004)

$$
\begin{array}{ll}
\text { 1. } & \text { Acquire } \\
\text { 2. } & \text { Enhance } \\
\text { 3. } & \text { Retain }
\end{array}
$$

\subsection{Electronic Customer Relationship Management (e- CRM) Definition}

A customer relationship management are held electronically. By using Internet technology, data about the customer can be easily integrated with marketing, sales, analysis and customer service applications (Turban et al., 2008) [6]. At present the world connected by the net technology and e-CRM has become one of a necessity for survival from competitive condition.

\subsection{Sharia Insurance Definition}

Dewan Syariah Nasional (DSN) incooperation with Majelis Ulama Indonesia (MUI) stated that Sharia Insurance is a business entity whose mutual protection and mutual help among people through investment in assets and or tabarru are on the pattern returns to face a particular risk through a contract in accordance with sharia. Aqad shariacompliant means any kind of contract that does not contain gharar (vagueness), maysir (speculation), usury, zhulum (persecution), risywah (bribes), haram and immoral acts (Al Arif, 2012) [7].

\section{Research Framework}

Research stages used are as follows: Started with collecting data using observation, and interviewing, mixing with distributing questioners, complement with literature studies. Next, it was working system development methods accentuating at waterfall models.

\section{Results and Discussions}

\subsection{Analysis of The Current System}

Based on analysis of the current system that has been done, there are some advantages and weaknesses in the current systems is at sharia life insurance AJB Bumiputera 1912 customers service, as follows:

1) Advantages:

1. Promotion of company and sharia life insurance products of AJB Bumiputera 1912 by utilizing the communication by mouth to mouth by the customers provide value to the recipient of information because the information provided is based on the experiences of customers itself, and it is certainly beneficial for the company anyway.

2. AJB Bumiputera has a selection of media services that can be accessed by the customers of conventional life insurance and sharia life insurance Bumiputera, there are a service agent, branch offices, call centers, SMS center, and company website.

3. Service agent intensify to customers.

2) Weaknesses:

1. There's not available for specialized information services media of sharia life insurance AJB Bumiputera 1912 that provides a variety of information up to date on the technical Bumiputera sharia life insurance, as well as other support services to facilitate the public in understanding sharia life insurance products offered by the company.

2. Services to sharia life insurance AJB Bumiputera 1912 customers is not optimal because it has not provided alternative online-based services for sharia life insurance Bumiputera customers that can be accessed quickly and easily at anytime and anywhere by customers without the need to come to the sharia branch offices or through the agent.

\subsection{Analysis of Proposed System}

From the analysis that has been described, the author proposed a system to overcome the problems on a running system is an Electronic Customer Relationship Management (e-CRM) information system on sharia life insurance AJB Bumiputera 1912. This system is intended for the company especially Sharia Division AJB Bumiputera 1912, the prospect of (visitors / potential customers), and customers. This proposed system is an alternative service for customers sharia life insurance AJB Bumiputera 1912 utilizing websites and internet-based systems as a media of information and services that can be easily accessed at anytime and anywhere.

\subsection{Design}

In the design phase, it is made in the form of diagrams that describe what processes and functions which exist in the system that will be created. Picture of the proposed system as follows: 


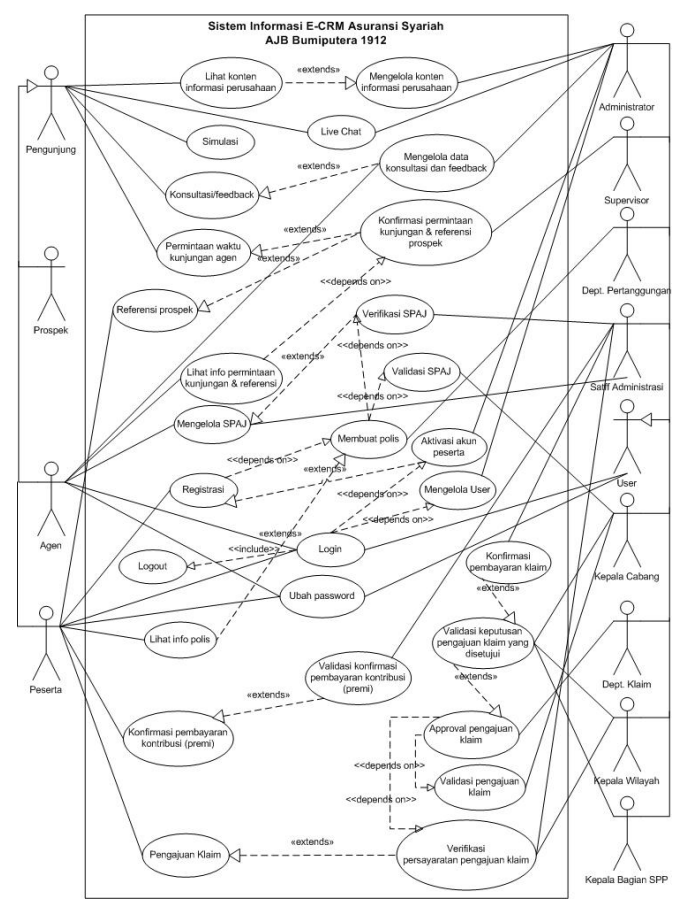

Figure 1. Use Case Diagram of E-CRM Sharia Life Insurance System of Bumiputera

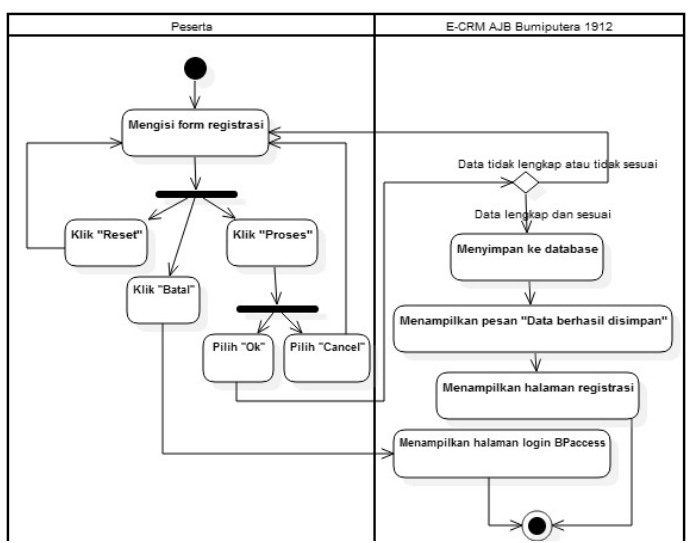

Figure 2. Activity Diagram of Registration

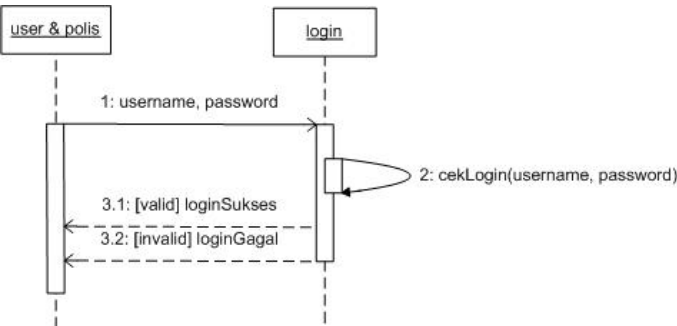

Figure 3. Sequence Diagram of Login

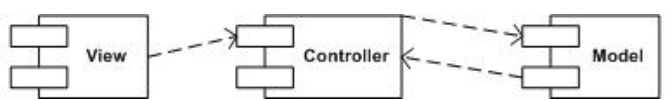

Figure 4. Component Diagram E-CRM Sharia Life Insurance System of Bumiputera

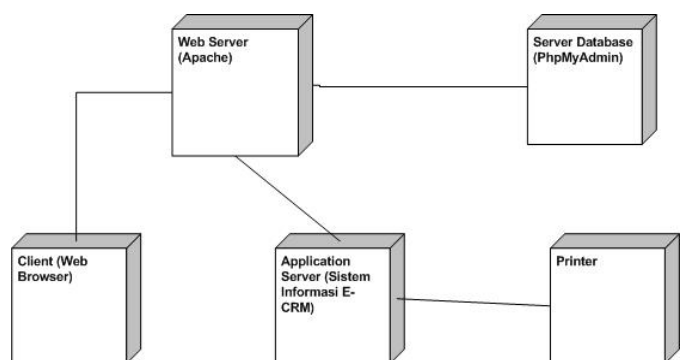

Figure 5. Deployment Diagram E-CRM Sharia Life Insurance System of Bumiputera

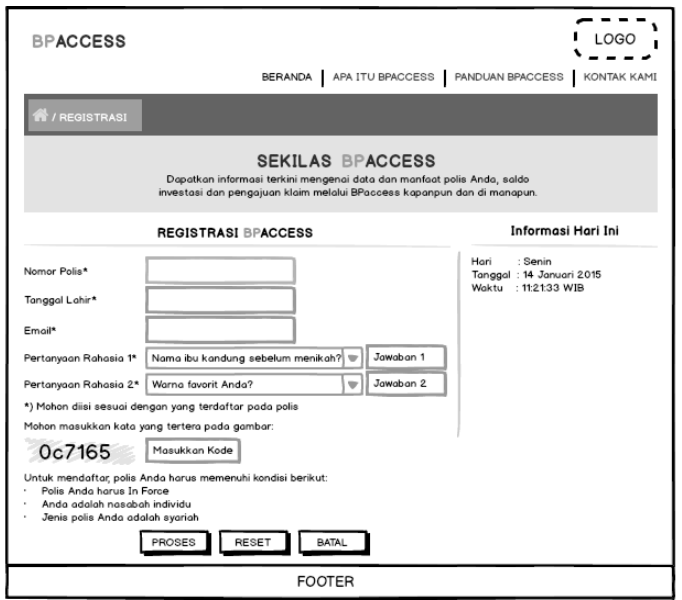

Figure 6. Interface of Customer Service System Registration

\section{Conclusion and Recommendation}

\subsection{Conclusion}

Based on the description and the previous discussion, it can be concluded that:

1. The Electronic Customer Relationship Management (e-CRM) information system for sharia life insurance AJB Bumiputera 1912 can facilitate Bumiputera in providing information about the company, sharia life insurance products, as well as other services that it offers to the public and insurance customers.

2. With the system, public becomes more easily access corporate information as well as life insurance products and services such as demand sharia visits Bumiputera agents, insurance simulation, as well as consultation and feedback. In addition, the insurance customers can more easily access the policy information, such as information due date contribution, contribution payment history, as well as the insurance customers progress filing insurance claims.

3. With reference feature on the prospect of such a system, Bumiputera also be helped in getting new insurance customer to reach a wider market on the reference of customer.

\subsection{Recommendation}

In the development of the Electronic Customer Relationship Management (e-CRM) Information System in Sharia Life Insurance AJB Bumiputera 1912 
is certainly still need to be developed further to be a better system, among others:

1. It should be created an automatic and scheduled backups system, so that the data that already exists can be stored properly.

2. Features on the system can be developed further, so that the information and services presented can be clearer and more complete for the customers and public.

3. The Electronic Customer Relationship Management (e-CRM) information system in sharia life insurance AJB Bumiputera 1912 could be developed in the mobile application version, so it can be accessed more easily.

\section{References}

[1] Kusrini and Koniyo, Andri. 2007. Tuntunan Praktis Membangun Sistem Informasi Akuntansi dengan Visual Basic dan Microsoft SQL Server. Yogyakarta: ANDI.

[2] Waspodo, Bayu. 2008. Sistem Informasi dan Prakteknya di Lembaga Usaha. Jurnal Penelitian \& Pengembangan 